\title{
Efektivitas Pelatihan Empati dalam Mengurangi Konflik Perkawinan pada Pasangan Suami Istri yang Berada pada Tahun Awal Pernikahan
}

\author{
Fatmawati, ${ }^{1}$ Rahima Nurviani, ${ }^{2}$ Ridha Ilham $^{3}$ \\ 1, 2 Liquid Konsultan, Banda Aceh - Indonesia; ${ }^{3}$ Badan Kependudukan dan Keluarga Berencana Nasional \\ Provinsi Aceh, Banda Aceh - Indonesia
}

\begin{abstract}
A conflict in marriage is something that cannot be avoided but must be faced. For this reason, in an effort to reduce or resolve a conflict that occurs, a couple of husband and wife must have effective communication. It includes showing of empathy, which requires the ability of husband and wife to listen to their partners attentively and be willing to receive messages from each other. This study aimed to examine the effectiveness of empathy training to reduce conflict in married couples in their early years of marriage. Empathy training was developed based on 4 empathy techniques, namely self-empathy, accepting others, accurate listening, and perspective taking. Empathy training was conducted on 14 couples who lived in Banda Aceh and Aceh Besar. They were selected using purposive sampling technique. The study used between group/pretest-posttest control group design and the data were collected with marital conflict scale. The results of data analysis showed that empathy training was effective to reduce marital conflict in married couples in the early years of marriage.
\end{abstract}

Keywords: early-year marriage; empathy training; marital conflict

\begin{abstract}
Abstrak: Konflik dalam perkawinan bukanlah hal yang perlu dihindari, tapi justru harus dihadapi. Dalam upaya untuk mengurangi atau menyelesaikan konflik yang terjadi, pasangan suami istri harus menjalin komunikasi yang efektif yang tentu tidak terlepas dari empati. Untuk itu, penelitian ini bertujuan menguji efektifitas pelatihan empati untuk menurunkan konflik perkawinan pada pasangan suami istri yang berada pada tahun awal pernikahan. Pelatihan empati dikembangkan berdasarkan 4 aspek empati yaitu self empathy, accepting others, accurate listening, dan perspective taking. Pelatihan empati dilakukan pada 14 pasangan suami istri yang berdomisili di Banda Aceh dan Aceh Besar yang direkrut melalui teknik purposive sampling. Rancangan penelitian menggunakan between group/pretest-posttest control group design dan data dikumpulkan dengan skala konflik dalam perkawinan. Hasil analisis data menunjukkan bahwa pelatihan empati efektif untuk menurunkan konflik perkawinan pada pasangan suami istri yang berada pada tahun awal pernikahan.
\end{abstract}

Kata Kunci: tahun awal pernikahan; pelatihan empati; konflik dalam perkawinan

Corresponding Author: Fatmawati (e-mail: fatmawatifadli@ar-raniry.ac.id). Liquid Konsultan. J. Tengku Imuem Lueng Bata. Banda Aceh. 


\section{Pendahuluan}

Konflik akan selalu hadir dalam sebuah kehidupan bersama, bahkan dalam hubungan yang erat sekalipun konflik merupakan hal yang tidak mungkin untuk dihindari. Konflik dapat bersumber dari hubungan interpersonal di mana terjadi persaingan antara dua pihak atau salah satu pihak mengeksploitasi pihak lainnya (Feeney \& Karantzas, 2017). Begitu juga halnya dengan kehidupan perkawinan, seringkali konflik tidak dapat dielakkan. Untuk itu, konflik tersebut perlu dikurangi atau diselesaikan agar tujuan perkawinan dapat dicapai. Kebahagiaan merupakan hal prioritas yang sangat diharapkan dalam sebuah perkawinan, seperti yang diungkapkan dalam Undang-Undang Nomor 52 Tahun 2009 tentang perkembangan kependudukan dan pengembangan keluarga bahwa pemerintah daerah mempunyai kewenangan dan tanggung jawab untuk mewujudkan keluarga yang berkualitas, dan keluarga yang berkualitas dapat tercapai jika dilandasi oleh kebahagiaan dalam perkawinan.

Meskipun demikian, kebahagiaan perkawinan merupakan sesuatu yang sulit untuk diraih jika pasangan suami istri tidak memiliki kualitas hubungan perkawinan yang tinggi di antara keduanya, karena dalam perjalanan mengarungi bahtera rumah tangga mereka dituntut melakukan penyesuaian terhadap peran dan tanggung jawab baru yang tentunya sangat berbeda dibandingkan saat pasangan suami istri tersebut belum menikah. Tidak dapat dipungkiri bahwa ketidakmampuan dalam menjalani proses ini akan menyebabkan timbulnya konflik dan pertentangan yang apabila tidak diselesaikan dengan baik maka dapat berujung pada perceraian (Johnson, Horne, Hardy, \& Anderson, 2018).

Hal ini telah dibuktikan dari sejumlah survei yang dilakukan di beberapa kawasan di Indonesia. Berdasarkan data Badan Pusat Statistik (2017) angka perceraian di Indonesia terus meningkat dari tahun ke tahun dan kondisi ini hampir merata di seluruh daerah. Misalnya, pada tahun 2012 angka cerai dan talak ditemukan sebanyak 346.480 kasus, kemudian turun menjadi 324.247 kasus di tahun 2013, lalu kembali meningkat pada tahun 2014 mencapai 344.237 kasus, dan terus naik hingga 347.256 kasus pada tahun 2015 . Lebih lanjut, Direktorat Jenderal Badan Peradilan Agama Mahkamah Agung menambahkan bahwa dalam kurun waktu tahun 2014 hingga 2016 jumlah perceraian di Indonesia memang melesat cukup tinggi. Pada 2014 tercatat sekitar 344.237 kasus perceraian, meningkat menjadi $365.633 \mathrm{di}$ tahun 2016. Jika dihitung lebih rinci, maka ratarata perceraian di Indonesia naik 3 persen setiap tahunnya (Muhyiddin \& Yulianto, 2018).

Di Provinsi Aceh, berdasar data Mahkamah Syar'iyah Aceh (2017) kasus perceraian di sepanjang tahun 2017 mencapai 5.399 kasus. Kasus cerai gugat lebih mendominasi yaitu 3.891 kasus daripada cerai talak sebanyak 1.508 kasus yang artinya banyak pihak perempuan yang menggugat pihak laki-laki. Selain itu, mayoritas kasus yang ditangani juga adalah pasangan yang usia pernikahannya masih sangat dini.

Oleh karena itu, penyelesaian konflik dalam perkawinan pada pasangan suami istri sangatlah diperlukan. Hal tersebut dilakukan untuk menghindari adanya perceraian, apalagi pasangan yang berusia muda dan usia pernikahannya muda sangat rentan terhadap konflik dibandingkan pasangan yang sudah lama menikah karena pengendalian emosi yang mereka miliki masih belum cukup baik (Pahlavan, Mahdiraji, Ahmadi, Asadi, \& Ahmadi, 2017). Walgito (2000) mengkategorikan sepuluh tahun pertama sebagai fase tahun awal pernikahan. Masa ini diwarnai oleh sikap saling mengenal dan menyesuaikan diri antara kedua belah pihak, termasuk memulai karir yang lebih mapan dalam pekerjaan, me- 
rencanakan kehadiran anak pertama, serta peran lainnya sebagai suami istri.

Untuk itu, dalam upaya untuk mengurangi atau menyelesaikan konflik yang muncul dalam rumah tangga, suami istri harus menjalin komunikasi yang efektif dengan melibatkan bahasa verbal dan non-verbal yang empati (Kouros \& Papp, 2018). Hal tersebut senada dengan yang dipaparkan oleh Dewi dan Sudhana (2013) bahwa salah satu faktor yang dapat mengurangi konflik dalam perkawinan adalah terbuka dalam mengkomunikasikan masalah yang ada dan berkompromi untuk mencari jalan keluar terbaik melalui cara bicara yang lemah lembut dan tidak disertai dengan emosi negatif. Tentu hal ini sangat sejalan dengan konsep komunikasi empati di mana suami istri diharapkan mampu memahami keluh kesah pasangannya dengan sepenuh hati dan bersedia menerima kekurangan yang dimiliki oleh pasangan apa adanya. Seseorang yang memiliki sifat empati juga diilustrasikan sebagai seorang dengan pribadi yang humanis di mana ia memiliki rasa toleransi yang tinggi dan mampu mengontrol diri dengan baik. Brigham (1991) mengartikan empati sebagai suatu kemampuan untuk memahami apa yang dirasakan oleh orang lain secara emosional. Lebih lanjut Brigham (1991) mengatakan bahwa tanpa keterampilan ini, hubungan yang telah dijalin bisa saja hancur karena keliru dalam menafsirkan perasaan akibat tumpulnya perasaan.

Terdapat beberapa program pelatihan empati yang telah diterapkan pada upaya peningkatan komunikasi bagi pasangan suami istri. Salah satunya adalah penelitian yang dilakukan oleh Ridzal (2017) yang telah menerapkan rancangan pelatihan empati dengan menggunakan pendekatan experiental learning untuk meningkatkan komunikasi intim pasangan suami istri. Hasil penelitian tersebut menunjukkan bahwa pelatihan empati terbukti dapat meningkatkan komunikasi intim antara suami dan istri. Namun demikian, sejauh studi literatur yang peneliti lakukan, belum ada pelatihan empati yang ditujukan untuk menurunkan konflik perkawinan, khususnya bagi pasangan yang masih berada pada fase awal pernikahan. Untuk itu, peneliti tertarik untuk mengungkap lebih jauh mengenai isu tersebut melalui penelitian ini, dengan tujuan untuk mengkaji efektivitas pelatihan empati dalam mengurangi konflik perkawinan pada pasangan suami istri yang berada pada tahun awal pernikahan. Hipotesis yang diajukan berbunyi pelatihan empati efektif menurunkan konflik dalam perkawinan bagi pasangan suami istri yang berada pada tahun awal pernikahan.

\section{Metode}

Penelitian ini dilakukan dengan menggunakan rancangan eksperimen between group/ pretest-posttest control group design, di mana randomisasi dilakukan untuk mengontrol kesetaraan proactive history antara kelompok kontrol dan kelompok eksperimen. Rancangan penelitian ini juga melibatkan pengukuran pada tiap-tiap kelompok, baik sebelum (pretest) ataupun sesudah (posttest) perlakuan diberikan. Lalu, sampel dipilih secara acak untuk kemudian ditempatkan dalam kelompok kontrol atau kelompok eksperimen, sehingga individu yang berada pada masing-masing kelompok tidaklah sama (Myers \& Hansen, 2011). Rancangan penelitian dapat dilihat dalam Gambar 1.

Jumlah subjek yang diperoleh dari hasil rekrutmen melalui penyebaran selebaran (flyer) berjumlah 18 pasang suami istri (36 orang), namun 4 pasang tidak memenuhi syarat sehingga tidak dapat diikutsertakan lebih lanjut. Subjek direkrut dengan teknik purposive sampling karena beberapa kriteria yang harus di penuhi, yaitu: 1) Berada pada usia pernikahan di bawah 10 tahun. 2) Memiliki tingkat konflik dalam perkawinan yang tinggi berdasarkan hasil pre-test (skor tinggi pada hasil skala konflik dalam perkawinan). 3) Belum pernah menerima 


\begin{tabular}{lccccc}
\hline $\begin{array}{l}\text { Randomisasi } \\
\text { (Kelompok) }\end{array}$ & Pre-test & & $\begin{array}{c}\text { Perlakuan } \\
\text { (pelatihan empati) }\end{array}$ & & Post-test \\
\hline $\mathrm{R}(\mathrm{KE})$ & $\mathrm{O}_{1}$ & $\rightarrow$ & $\mathrm{X}$ & $\rightarrow$ & $\mathrm{O}_{2}$ \\
$\mathrm{R}(\mathrm{KK})$ & $\mathrm{O}_{1}$ & $\rightarrow$ & - & $\rightarrow$ & $\mathrm{O}_{2}$ \\
\hline
\end{tabular}

Gambar 1. Rancangan Penelitian

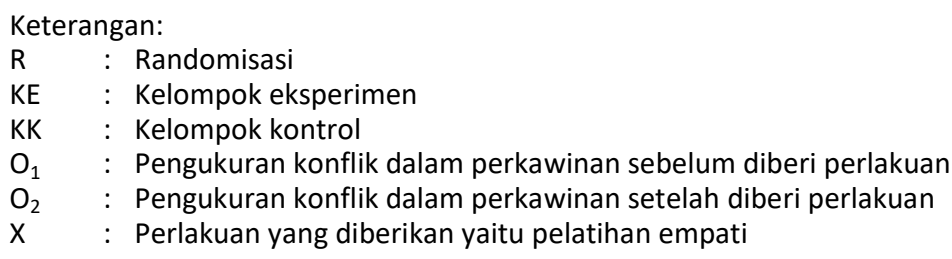

intervensi terkait dengan konflik dalam perkawinan. 4). Tinggal bersama atau tidak menjalani hubungan perkawinan jarak jauh.

Pengukuran konflik dalam perkawinan dilakukan dengan menggunakan skala konflik dalam perkawinan yang dikembangkan dari teori Gottman dan Declaire (dalam Miga, Gdula, \& Allen, 2012) yang terdiri dari aspek-aspek berikut: 1) Partner violence, yakni konflik yang ditunjukkan dalam bentuk kekerasan fisik pada pasangan. 2) Verbal aggression, yakni kekerasan verbal yang muncul dalam bentuk penghinaan, kecaman, atau ancaman terhadap pasangan. 3) Unbending stance, yaitu upaya mempertahankan diri sebagai bentuk membela diri saat konflik terjadi atas penghinaan dari pasangannya. 4) Withdraw from partner, yakni menarik diri atau menghindari interaksi dengan pasangan yang biasanya ditunjukkan dengan perilaku diam.

Skala konflik dalam perkawinan yang terdiri dari aspek-aspek di atas kemudian telah diadaptasi oleh Dewi dan Basti (2008) dan juga telah diuji reliabilitasnya dengan nilai Cronbach's $\alpha$ sebesar 0.763. Menurut Ghozali (2006) sebuah skala dinyatakan reliabel jika memiliki nilai Cronbach's $\alpha$ mendekati angka 1,00. Dengan demikian, dapat disimpulkan bahwa skala konflik dalam perkawinan yang digunakan dalam penelitian ini merupakan skala yang reliabel. Kemudian skor konflik dalam perkawinan antara suami dan istri yang berada pada tahun awal pernikahan diperoleh dari skor total seluruh aspek dari skala konflik dalam perkawinan yang menunjukkan tingkat konflik yang terjadi antara suami dan istri. Semakin tinggi skor total yang diperoleh, maka semakin tinggi tingkat konflik yang terjadi, demikian pula sebaliknya semakin rendah skor total yang diperoleh, maka semakin rendah tingkat konflik yang terjadi antara suami dan istri. Berdasarkan screening dengan menggunakan skala tersebut, sejumlah 4 pasang suami istri tidak dapat diikutsertakan dalam pelatihan karena skor konflik perkawinan yang rendah sehingga tidak memenuhi kriteria yang telah ditentukan dalam penelitian ini.

Selanjutnya, subjek yang telah memenuhi seluruh kriteria di atas dan berada dalam kelompok eksperimen diberikan intervensi berupa pelatihan empati, sedangkan subjek yang berada dalam kelompok kontrol tidak menerima intervensi apapun. Pelatihan empati ini terdiri dari empat modul dengan masing-masing berdurasi 4 jam yang dibuat berdasarkan aspek empati dari Rutsch (2013). Empat modul tersebut adalah self-empathy, accepting others, accurate listening, dan perspective taking. Pada aspek self-empathy peserta dilatih untuk ber- 
empati terhadap dirinya sendiri. Pada aspek accepting other peserta tahu bagaimana berempati terhadap orang lain dan dapat menerapkannya dalam situasi kehidupan nyata. Lalu, pada aspek accurate listening peserta diajarkan bagaimana cara mendengarkan secara akurat, dapat mendengarkan pembicara tanpa menambahkan, dan dapat mencerminkan perasaan dan pikiran pembicara dengan benar. Terakhir, pada aspek perspective taking peserta diharapkan mampu memiliki titik pandangnya sendiri dan tahu perspektif sendiri tidak selalu sama dengan orang lain (Wahyuni, 2017).

Setiap modul dimulai dengan review singkat mengenai modul sebelumnya dan assignment yang diberikan. Setelah itu pelatih memberikan materi mengenai modul yang diberikan dan pada saat tersebut peserta juga ditanyakan mengenai pemikiran awal yang diketahui mengenai materi. Setelah masukan dari peserta didapatkan, selanjutnya pelatih menyajikan informasi lebih lanjut tentang materi tersebut. Berikutnya peserta diberikan tugas yang berbeda untuk berlatih mengenai materi yang telah disampaikan. Akhirnya pemberian materi diakhiri dengan evaluasi secara singkat. Metode penilaian bervariasi tergantung pada tujuan dari modul. Peserta juga diberi tugas rumah yang dikerjakan sebagai pengayaan di rumah.

Intervensi pelatihan empati ini dilaksanakan selama 4 kali pertemuan mulai tanggal 28 Agustus hingga 5 September 2018 pada pagi hari dimulai pukul 08.00 WIB hingga selesai. Pertemuan dilakukan 2 kali dalam seminggu yaitu pada hari Sabtu dan Minggu dengan pertimbangan subjek yang harus bekerja pada hari lainnya. Lalu, pertemuan kelima (1 minggu setelah pertemuan terakhir) digunakan untuk dilaksanakannya posttest pada kelompok eksperimen dan kelompok kontrol. Intervensi pelatihan empati dilakukan di salah satu ruangan kantor Liquid Konsultan Banda Aceh.
Analisis data dalam penelitian ini dilakukan dengan menggunakan statistika non parametrik Wilcoxon dan Mann-Whitney melalui bantuan Program SPSS for Windows versi 20.0 karena pertimbangan jumlah sampel yang kurang dari 30 orang (Field \& Hole, 2003). Analisis Wilcoxon digunakan untuk menguji beda skor konflik dalam perkawinan antara pretest dan posttest pada kelompok kontrol dan kelompok eksperimen. Sedangkan analisis Mann-Whitney digunakan untuk menguji perbedaan skor pretest antara kelompok eksperimen dan kelompok kontrol, serta perbedaan skor posttest antara kelompok eksperimen dan kelompok kontrol.

\section{Hasil}

Subjek penelitian ini berjumlah 28 orang $(14$ pasang suami istri), yang terbagi ke dalam kelompok eksperimen 14 orang ( 7 pasang suami istri) dan kelompok kontrol 14 orang (7 pasang suami istri). Subjek ditempatkan dalam kedua kelompok secara random. Adapun karakteristik subjek penelitian secara umum dapat dilihat dari Tabel 1. Mayoritas subjek memiliki usia perkawinan 2 dan 3 tahun yaitu masing-masing sebanyak 3 pasang, di mana usia pernikahan 2 tahun seluruhnya (21.42\%) berada di kelompok eksperimen, sedangkan usia pernikahan 3 tahun, 1 pasang (7.14\%) berada pada kelompok eksperimen dan 2 pasang (14.28\%) berada pada kelompok kontrol. Untuk daerah domisili sebarannya sama antara Banda Aceh dan Aceh Besar yaitu masing-masing 7 pasang untuk setiap wilayah. Subjek yang tinggal mandiri lebih dominan dalam penelitian ini, yaitu sekitar 9 pasang (64.28\%), dibandingkan subjek yang tinggal bersama keluarga suami atau istri.

Analisis lebih lanjut mengenai konflik perkawinan dari kelompok eksperimen dan kelompok kontrol dilakukan dengan menggunakan statistik deskriptif. Berdasarkan analisis tersebut terlihat bahwa ada perbedaan rata-rata 
Tabel 1.

Karakteristik Subjek Penelitian

\begin{tabular}{llcccc}
\hline & \multirow{2}{*}{ Karakteristik Subjek } & \multicolumn{2}{c}{ Kelompok Eksperimen } & \multicolumn{2}{c}{ Kelompok Kontrol } \\
& & $\mathrm{n}=7$ pasang & $\mathrm{n} \%$ & $\mathrm{n}=7$ pasang & $(\mathrm{n} \%)$ \\
\hline Usia Perkawinan & 2 tahun & 3 & 21.42 & 0 & 0 \\
& 3 tahun & 1 & 7.14 & 2 & 14.28 \\
& 4 tahun & 1 & 7.14 & 0 & 0 \\
& 5 tahun & 0 & 0 & 1 & 7.14 \\
& 6 tahun & 1 & 7.14 & 1 & 7.14 \\
& 7 tahun & 0 & 0 & 7.14 \\
& 8 tahun & 0 & 0 & 1 & 0 \\
& 9 tahun & 0 & 0 & 1 & 7.14 \\
& 10 tahun & 1 & 7.14 & 3 & 7.14 \\
\hline Daerah Domisili & Banda Aceh & 4 & 28.57 & 21.42 \\
& Aceh Besar & 3 & 21.42 & 4 & 28.57 \\
\hline Tempat Tinggal & Mandiri & 4 & 28.57 & 5 & 35.71 \\
& Bersama keluarga suami & 0 & 0 & 1 & 7.14 \\
\hline
\end{tabular}

antara pretest dan posttest, baik pada kelompok eksperimen maupun pada kelompok kontrol. Hal ini menandakan bahwa skor konflik dalam perkawinan saat pretest dan posttest pada masingmasing kelompok berbeda. Hasil analisis tersebut dapat dilihat pada Tabel 2.

Hasil analisis Mann-Whitney terhadap skor posttest pada kelompok eksperimen dan kelompok kontrol diperoleh skor $\mathrm{Z}=-4.540$ dengan $p=0.000(p<0.05)$. Berdasarkan analisis tersebut diketahui bahwa terdapat perbedaan antara posttest pada kelompok eksperimen dengan kelompok kontrol. Artinya, ada penurunan konflik dalam perkawinan pada kelompok eksperimen setelah pelatihan empati diberikan, sedang- kan kelompok kontrol yang tidak mendapatkan pelatihan empati tidak mengalami penurunan konflik dalam perkawinan.

Lebih lanjut, hasil uji komparatif (Wilcoxon) pada kelompok eksperimen menunjukkan adanya perbedaan konflik dalam perkawinan yang signifikan $(\mathrm{p}<0.05)$ antara pretest dan posttest. Hal ini juga dibuktikan oleh skor rata-rata posttest (Mean=17.21) kelompok eksperimen yang lebih rendah dibandingkan dengan skor rata-rata saat pretest (Mean=23.93). Adanya selisih rata-rata sebesar 6.72 antara pretest dan posttest memiliki makna bahwa pemberian pelatihan empati signifikan dalam menurunkan konflik dalam perkawinan antara pretest dan posttest.

Tabel 2.

Statistik Deskriptif Kelompok Eksperimen dan Kontrol

\begin{tabular}{lllllll}
\hline $\begin{array}{l}\text { Data Konflik dalam } \\
\text { Perkawinan }\end{array}$ & Kelompok & N & Mean & SD & Max & Min \\
\hline Pretest & Eksperimen & 14 & 23.93 & 4.08 & 33 & 21 \\
& Kontrol & 14 & 24.57 & 3.54 & 31 & 21 \\
\hline Posttest & Eksperimen & 14 & 17.21 & 2.11 & 19 & 13 \\
& Kontrol & 14 & 24.86 & 3.71 & 31 & 17 \\
\hline
\end{tabular}


Efektivitas Pelatihan Empati dalam Mengurangi Konflik Perkawinan ....

Tabel 3.

Hasil Uji Komparatif (Wilcoxon) Kelompok Eksperimen dan Kontrol

\begin{tabular}{lccccl}
\hline Kelompok & $\begin{array}{c}\text { Mean } \\
\text { Pretest }\end{array}$ & $\begin{array}{c}\text { Mean } \\
\text { Posttest }\end{array}$ & $\mathrm{Z}$ & $\mathrm{P}$ & Kesimpulan \\
\hline Eksperimen & 23.93 & 17.21 & -3.303 & 0.001 & Signifikan \\
\hline Kontrol & 24.57 & 24.86 & -1.414 & 0.157 & Tidak Signifikan \\
\hline
\end{tabular}

Sementara itu, hasil uji komparatif (Wilcoxon) pada kelompok kontrol menunjukkan tidak ada perbedaan konflik dalam perkawinan yang signifikan ( $>0.05)$ antara pretest dan posttest. Hal ini dapat dibuktikan dari skor rata-rata posttest (Mean=24.86) kelompok kontrol yang tidak jauh berbeda dibandingkan dengan skor rata-rata saat pretest (Mean=24.57). Rangkuman hasil uji komparatif (Wilcoxon) kelompok eksperimen dan kelompok kontrol pada saat pretest dengan posttest dapat dilihat pada Tabel 3 .

Berdasarkan analisis data tersebut, maka dapat ditarik kesimpulan bahwa hipotesis yang diajukan dalam penelitian ini diterima bahwa pelatihan empati efektif dalam menurunkan konflik dalam perkawinan pada pasangan suami istri yang berada pada tahun awal pernikahan. Dengan kata lain, terbukti bahwa terjadi penurunan konflik dalam perkawinan pada kelompok eksperimen antara sebelum dan setelah diberikan pelatihan empati.

\section{Diskusi}

Intervensi pelatihan empati dalam penelitian ini dirancang dengan tujuan untuk menurunkan konflik dalam perkawinan pada pasangan yang berada pada tahun awal pernikahan. Setelah intervensi pelatihan empati diberikan, diperoleh hasil bahwa pelatihan empati efektif untuk menurunkan konflik dalam perkawinan pada pasangan yang berada pada tahun awal pernikahan. Penurunan konflik dalam perkawinan ini dibuktikan dengan uji Mann-Whitney yang menunjukkan bahwa terdapat perbedaan konflik dalam perkawinan pada kelompok eksperimen dan kelompok kontrol. Perbedaan ini membuktikan adanya penurunan konflik dalam perkawinan pada pasangan yang berada pada tahun awal pernikahan yang diberikan pelatihan empati. Gambar 2 menunjukkan perbandingan pretest dan posttest skor konflik dalam perkawinan antara kelompok kontrol dan kelompok eksperimen.

Gambar 2 menunjukkan bahwa pada saat pretest, kelompok eksperimen memiliki mean skor konflik dalam perkawinan sebesar 23.93, sedangkan mean skor konflik dalam perkawinan kelompok kontrol sebesar 24.57. Berdasarkan hasil uji statistik dengan menggunakan Mann Whitney, perbedaan skor sebesar 0.64 ini menunjukkan bahwa skor pretest skala konflik dalam perkawinan kelompok eksperimen dan kelompok kontrol tidak berbeda secara signifikan. Dengan demikian dapat dikatakan bahwa kelompok eksperimen dan kelompok kontrol memiliki tingkat konflik dalam perkawinan yang sama (kategori tinggi) pada saat sebelum pemberian pelatihan empati.

Selain itu, Gambar 2 juga menunjukkan bahwa pada saat pengukuran setelah pemberian pelatihan empati (posttest), terlihat kelompok eksperimen mengalami penurunan mean skor konflik dalam perkawinan, sedangkan kelompok kontrol tidak mengalami penurunan mean skor konflik dalam perkawinan.

Konflik dalam perkawinan merupakan hal yang harus dihadapi bukan untuk dihindari, karena pada hakikatnya perkawinan terjadi akibat penyatuan dua individu dengan latar belakang yang sangat berbeda, baik dari segi budaya mau- 


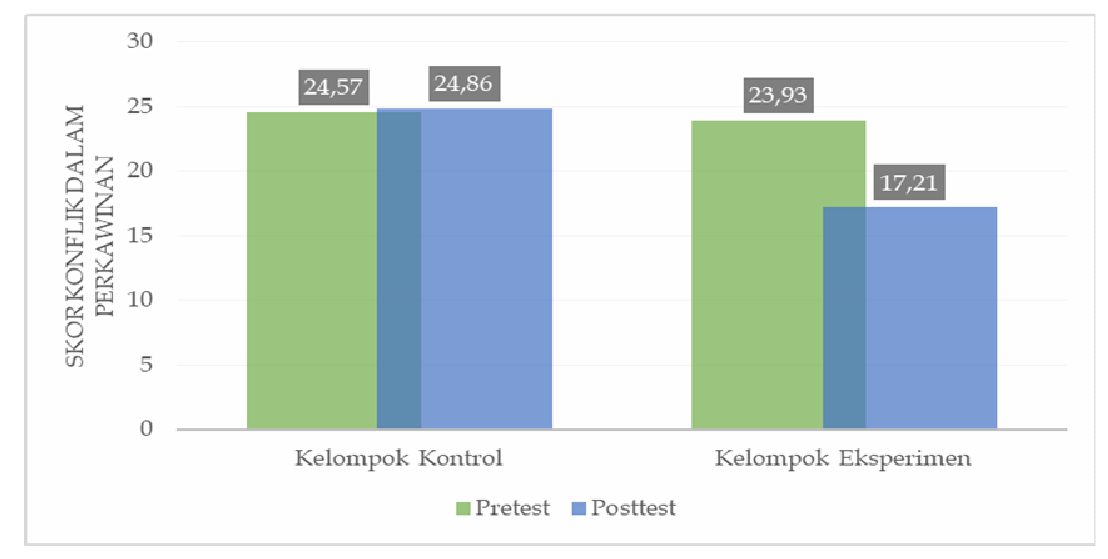

Gambar 2. Perbandingan Pretest dan Posttest skor Konflik dalam Perkawinan antara Kelompok Kontrol dan Kelompok Eksperime

pun pengalaman. Perbedaan ini tentunya menuntut keterampilan menyesuaikan diri yang cukup baik agar tidak menimbulkan banyak ketegangan nantinya (Miga et al,, 2012). McGonagle (dalam Sears, Freedman, \& Peplau, 1999) menyatakan bahwa konflik adalah hal biasa yang sering terjadi dalam kehidupan rumah tangga. Hal tersebut senada dengan penelitian yang telah dilakukan oleh Gurin (dalam Sears et al., 1999) yang menyebutkan bahwa $45 \%$ pasangan yang sudah menikah mengalami berbagai masalah dalam kehidupan rumah tangga mereka, dan $32 \%$ pasangan yang memiliki pernikahan bahagia juga pernah mengalami pertentangan atau konflik.

Untuk itu, komunikasi yang efektif merupakan salah satu fondasi dasar dalam menyelesaikan konflik dalam pernikahan dan jika hal ini berhasil dilakukan maka kepuasan pernikahan akan terbentuk (Sari \& Fauziah, 2016). Menurut Kouros dan Papp (2018) salah satu ciri utama dari komunikasi yang efektif dalam rumah tangga adalah adanya empati di mana suami atau istri bisa menempatkan diri pada situasi yang dihadapi atau dialami pasangan. Empati sangat penting karena melalui keterampilan ini seseorang mampu menunjukkan ekspresi dan pe- rasaan bahwa ia memahami apa yang dirasakan oleh pasangan. Pemahaman perasaan yang menjadi unsur komunikasi yang empati ini tentu tidak terlepas dari salah satu aspek empati yaitu accurate listening. Modul ke-3 yang dilatih dalam pelatihan ini bermakna bahwa seseorang dikatakan berempati jika ia mampu mendengarkan dengan baik apa yang disampaikan oleh pembicara dan mampu mencerminkan perasaan dan pikiran dari pembicara secara akurat. Aspek ini merupakan aspek penting karena dengan accurate listening seseorang dapat berkomunikasi melalui indera dari perspektif orang lain dan membantu dirinya untuk memahami perasaan, pikiran, dan dapat memaknai diri mereka sendiri dan menjadi kesatuan dengan diri mereka sendiri. Hal tersebut pada akhirnya menyebabkan timbulnya kesadaran dan wawasan yang lebih luas. Selanjutnya dengan mendengarkan secara akurat dengan orang lain maka dapat menciptakan hubungan yang lebih baik dan mendalam (Wahyuni, 2017).

Lebih lanjut dikatakan bahwa empati merupakan kemampuan holistik yang mencakup respon afektif berupa pemahaman perasaan individu lain. Melalui kemampuan empati seseorang dapat membangun akar relasi interper- 
sonal dengan baik dan kelak apabila dalam hubungan tersebut terjadi konflik, maka empati dapat dijadikan sebagai salah satu sumber koping (Ridzal, 2017).

Penelitian ini memiliki kekuatan maupun keterbatasan. Kekuatan dari penelitian ini adalah: Pertama, pelatihan empati diterapkan dengan cara melibatkan subjek dalam diskusi, review materi sebelumnya, aktivitas, presentasi, evaluasi materi, dan tugas rumah. Hal tersebut seperti penelitian yang dilakukan oleh Silverman (2014), Şahin (2012) bahwa aktivitas, interaksi, dan ceramah yang dilakukan selama pelatihan dapat membantu peserta dalam mengidentifikasi pengalaman emosional mereka. Tugas rumah diberikan untuk mendorong subjek agar terus secara aktif memikirkan dan terlibat dalam pengakuan emosional selama kehidupan sehari-hari. Hasil eksperimen Şahin (2012) menunjukkan bahwa terjadi peningkatan empati pada kelompok eksperimen dibandingkan kelompok kontrol.

Kedua, penelitian dilakukan dalam kelompok. Pelaksanaan pelatihan empati dalam kelompok merupakan faktor yang mendukung efektivitas pelatihan empati dalam meningkatkan empati subjek. Melalui kegiatan pengerjaan lembar kerja, seluruh subjek dapat saling mengetahui bahwa teman-temannya dalam pelatihan juga mengalami konflik dalam perkawinan yang hampir serupa dengan yang dirinya. Pengalamanpengalaman subjek yang dibagi dengan temantemannya melalui penerapan metode diskusi kelompok membuat subjek saling membantu untuk memahami materi yang diberikan, menjadi lebih terbuka, dan saling mendorong untuk memperbaiki diri, yakni menerapkan komitmen dan keterampilan yang mereka dapat dari pelatihan. Menurut Corey (2003) hal ini terjadi karena dalam kelompok, setiap anggota merasa mengalami permasalahan yang serupa sehingga mereka akan saling mendukung dan memberi inspirasi kepada anggota lainnya. Dalam kinerja berkelompok, umpan balik akan sangat bermanfaat sehingga saran-saran yang diterima mampu meningkatkan performansi, di mana hal ini tidak ditemukan dalam pelatihan individual (Bernard, Ellis, \& Terjesen, 2006).

Diterapkannya pelatihan empati di dalam kelompok juga dapat membantu peserta untuk dapat melatih kemampuan empatinya. Subjek diminta untuk berempati terhadap orang lain yang sedang mengikuti pelatihan empati. Subjek diminta untuk memahami kebutuhan orang lain dengan cara tidak ribut dan membuat kebisingan yang dapat mengganggu peserta lain dalam pelatihan empati. Seperti pernyataan yang disampaikan oleh Ylldı dan Duy (2013) bahwa empati merupakan kemampuan memahami orang lain yang merupakan aspek terpenting dalam hubungan interpersonal.

Ketiga, review materi setiap kali memulai sesi baru dianggap cukup efektif dalam pelatihan ini. Hal ini dikarenakan peneliti dapat mengetahui sejauh mana subjek dapat menangkap setiap materi yang diberikan pada tiap-tiap sesi. Berdasarkan pengulangan materi yang dilakukan, terlihat bahwa subjek memahami materi sebelumnya sehingga materi berikutnya dapat terus dilanjutkan dan kelancaran pelatihan dapat terjaga. Beck (2011) mengungkapkan bahwa dalam proses terapi, pengulangan materi atau review sangat diperlukan, karena baik klien maupun terapis dapat melacak sejauhmana kemajuan terapi yang sedang dijalankan. Hal yang sama juga terjadi pada proses pelatihan di mana fasilitator berperan menjadi terapis yang berperan untuk meninjau sejauhmana subjek memahami proses pelatihan, sedangkan subjek di sini seperti klien di mana review dapat berfungsi sebagai pengingat berbagai informasi yang telah diterima sebelumnya.

Adapun keterbatasan dari penelitian ini antara lain tidak adanya pengukuran follow-up setelah posttest dilakukan sehingga sulit untuk 
melacak apakah efek dari intervensi dapat bertahan lama atau tidak.

\section{Simpulan}

Berdasarkan paparan di atas, maka dapat ditarik sejumlah kesimpulan sebagai berikut, yaitu: 1) Pemberian pelatihan empati terbukti efektif untuk menurunkan konflik dalam perkawinan pada pasangan suami istri yang berada pada tahun awal pernikahan. Hal ini dapat dilihat adanya penurunan skor dalam skala konflik dalam perkawinan setelah pemberian pelatihan. 2) Hasil penelitian juga menunjukkan bahwa seluruh subjek pada kelompok eksperimen mengalami penurunan konflik dalam perkawinan.

\section{Saran}

Beberapa saran yang peneliti ajukan berdasarkan hasil yang diperoleh dalam penelitian ini: 1) Guna melihat perbandingan efektivitas pelatihan empati dengan pelatihan atau terapi lainnya dalam menurunkan konflik dalam perkawinan, perlu dilaksanakan penelitian lanjutan dengan desain penelitian yang berbeda, misalnya dengan membandingkan pelatihan empati dengan jenis intervensi lainnya untuk menangani masalah yang sama. 2) Untuk memantau pemeliharaan dan stabilitas perubahan konflik dalam perkawinan yang dihasilkan dari intervensi, studi selanjutnya sebaiknya mencakup pengukuran tindak lanjut (follow-up) dalam durasi yang lebih lama. Hal ini juga dapat dilakukan untuk melihat seberapa lama efek dari pelatihan empati berpengaruh terhadap konflik dalam perkawinan. 3) Bagi subjek penelitian diharapkan dapat tetap menerapkan teknik-teknik yang telah dipelajari selama pelaksanaan intervensi pelatihan empati, sehingga dapat menangani konflik dalam perkawinan dengan lebih baik. 4) Hasil penelitian ini diharapkan dapat memberikan informasi pada lembaga pemerintahan terkait fenomena konflik yang terjadi pada pasangan suami istri yang berada pada tahun awal pernikahan dan salah satu upaya pencegahan atau penanganan yang dapat diberikan agar konflik berkurang adalah dengan meningkatkan empati pada pasangan suami istri tersebut.]

\section{Daftar Pustaka}

Badan Pusat Statistik. (2017). Nikah, talak dan cerai, serta rujuk 2012-2015. Jakarta: Badan Pusat Statistik.

Beck, J. S. (2011). Cognitive behavior therapy: Basic and Beyond (2nd ed.). New York, London: The Guilford Press.

Bernard, M. E., Ellis, A., \& Terjesen, M. (2006). Rational-emotive behavioral approaches to childhood disorders: History, theory, practice and research. In M. E. Bernard \& A. Ellis (Eds.), Rational Emotive Behavioral Approaches to Childhood Disorders (pp. 3-84). Boston: Kluwer Academic Publishers. https://doi.org/10.1007/0-387-26375-6_1

Brigham, J. C. (1991). Social psychology (2nd ed.). New York: Harper Collins Publishers. Retrieved from https://www.worldcatorg/title/social-psychology/oclc/750972996

Corey, G. (2003). Teori dan praktek konseling \& psikoterapi. (E. Koeswara, Terj.). Bandung: Refika Aditama.

Dewi, E. M. P., \& Basti. (2008). Konflik perkawinan dan model penyelesaian konflik pada pasangan suami istri. Jurnal Psikologi, 2(No.1), 42-51. 
Dewi, N. R., \& Sudhana, H. (2013). Hubungan antara komunikasi interpersonal pasutri dengan keharmonisan dalam pernikahan. Jurnal Psikologi Udayana, 1(1), 22-31.

Feeney, J. A., \& Karantzas, G. C. (2017). Couple conflict: Insights from an attachment perspective. Current Opinion in Psychology, 13, 60-64. https://doi.org/10.1016/j.copsyc.2016.04.017

Field, A., \& Hole, G. j. (2003). How to design and report experiments. London, Thousand Oaks, Calif: Sage Publication Inc.

Ghozali, I. (2006). Aplikasi analisis multivariate dengan program SPSS. Semarang: Badan Penerbit Universitas Diponegoro.

Johnson, M. D., Horne, R. M., Hardy, N. R., \& Anderson, J. R. (2018). Temporality of couple conflict and relationship perceptions. Journal of Family Psychology, 32(4), 445-455. https://doi.org/ 10.1037/fam0000398

Kouros, C. D., \& Papp, L. M. (2018). Couples' Perceptions of Each Other's Daily Affect: Empathic Accuracy, Assumed Similarity, and Indirect Accuracy. Family Process. https://doi.org/10.1111/ famp.12344

Mahkamah Syar'iyah Aceh. (2017). Data perceraian di Aceh 2017. Banda Aceh: Mahkamah Syar'iyah Aceh.

Miga, E. M., Gdula, J. A., \& Allen, J. P. (2012). Fighting Fair: Adaptive Marital Conflict Strategies as Predictors of Future Adolescent Peer and Romantic Relationship Quality. Social Development, 21(3), 443-460. https://doi.org/10.1111/j.1467-9507.2011.00636.x

Muhyiddin, \& Yulianto, A. (2018). Ratusan ribu kasus perceraian terjadi dalam setahun. Retrieved from https://www.republika.co.id/berita/dunia-islam/islam-nusantara/18/01/21/p2w4v9396ratusan-ribu-kasus-perceraian-terjadi-dalam-setahun

Myers, A., \& Hansen, C. H. (2011). Experimental psychology. Belmont, CA: Wadsworth Publishing.

Pahlavan, M., Mahdiraji, M. A., Ahmadi, E. A. Y., Asadi, M., \& Ahmadi, R. A. A. Y. (2017). A sociological study on the effect of the virtual network (telegram) on emotional divorce among young couples (A case study of Babol Payam Noor Center). Sociological Studies of Youth, 8(25), 71-80. Retrieved from http://ssyj.baboliau.ac.ir/article_530804.html

Ridzal, A. R. S. (2017). Rancangan pelatihan empati terhadap kemampuan berkomunikasi intim pasangan suami istri. Schema: Journal of Psychological Research, 3(1), 69-78. https://doi.org/ 10.1134/S1995082911030114

Rutsch, E. (2013). Increasing empathy: Manual empathy training. Washington DC.: The Center for Building a Culture of Empathy and Compassion. Retrieved from http://cultureofempathy.com/ References/Experts/Others/Files/Marieke-Kingma-Empathy-Training-Manual.pdf

Şahin, M. (2012). An investigation into the efficiency of empathy training program on preventing bullying in primary schools. Children and Youth Services Review, 34(7), 1325-1330. https://doi.org/10.1016/j.childyouth.2012.03.013

Sari, A. N., \& Fauziah, N. (2016). Hubungan antara empati dengan kepuasan pernikahan pada suami yang memiliki istri bekerja. Jurnal Empati, 5(4), 667-672. Retrieved from https://ejournal3. undip.ac.id/index.php/empati/article/view/15432

Sears, D. O., Freedman, J. L., \& Peplau, L. A. (1999). Psikologi sosial. (M. Adryanto \& S. Soekrisno, Eds.). Jakarta: Erlangga.

Silverman, M. J. (2014). Effects of music therapy on drug avoidance self-efficacy in patients on a detoxification unit: A three-group randomized effectiveness study. Journal of Addictions Nursing, 25(4), 172-181. https://doi.org/10.1097/JAN.0000000000000047 
Wahyuni, P. (2017). Efektivitas empathy training untuk meningkatkan empathy pada remaja awal pelaku bullying. Medan: Universitas Sumatera Utara.

Walgito, B. (2000). Bimbingan dan konseling perkawinan. Yogyakarta: Penerbit Andi.

Ylldız, M. A., \& Duy, B. (2013). Improving empathy and communication skills of visually impaired early adolescents through a psycho-education program. Educational Sciences: Theory and Practice, $13,1470-1476$. 